\title{
GOOGLE APPS UNTUK PROSES PEMBELAJARAN DI FAKULTAS TEKNOLOGI INFORMASI (FTI), UNIVERSITAS RESPATI INDONESIA
}

\author{
Andi Susilo ${ }^{1}$, Yasmiati ${ }^{2}$ \\ Program Studi Teknik Informatika, Fakultas Teknologi Informasi, Universitas Respati Indonesia \\ Jl. Bambu Apus I No.3, Cipayung, Jakarta 13890 \\ Telp. (021) 8457627 , Faks. (021) 8457628 \\ E-mail:as@fti.urindo.ac.id,yasmiati@fti.urindo.ac.id
}

\begin{abstract}
ABSTRAK
FTI dibuka pada tanggal 6 Juni 1986. Saat ini jumlah populasi mahasiswa FTI sebanyak 45lorang dan jumlah alumni empat tahun terakhir sebanyak 102 mahasiswa. FTI memiliki dua program studi Teknik Informatika dan Sistem Informasi. Interaksi dan kolaborasi mahasiswa dalam proses pembelajaran secara online yang melibatkan Teknologi Informasi masih sangat kurang, tidak adanya Perencanaan Strategis Sistem Informasi dan Infrastruktur TI mengakibatkan dukungan TI terhadap aktivitas akademik tidak mencapai sasaran, kebijakan pendelegasian terhadap manajemen penggunaan domain juga tidak jelas sehingga saat ini email dengan domain universitas praktis tidak dimiliki baik oleh dosen, mahasiswa, maupun staf universitas. Pengalaman adaptasi ke Google Apps standar pada tahun 2008 secara parsial menjadi dasar pertimbangan untuk melakukan migrasi email dan perbaikan aktivitas belajar melalui Blended Learning dengan mengimplementasikan Google Apps for Education sebagai Cloud Computing pada akhir tahun 2010. Servis telah diaktifkan meliputi Gmail, Google Sites, Google Docs, Gtalk, Google Calendar, Google Groups, Postini Services, dan Google Contacts dengan subdomain fti.urindo.ac.id. Tahap perencanaan deployment teknis untuk menjalankan Google Apps pilot sedang dilakukan. Implementasi menyeluruh dengan melibatkan komponen di fakultas diharapkan dapat memperbaiki layanan kepada mahasiswa, dosen, dan staf di fakultas, juga mengurangi biaya yang signifikan terhadap investasi software dan hardware dari lemahnya perencanaan TI.
\end{abstract}

Kata Kunci: google apps, cloud computing, blended learning

\section{PENDAHULUAN}

\subsection{Latar Belakang}

Universitas Respati Indonesia (Urindo) berdiri sejak tahun 1998 saat ini memiliki 5 fakultas dengan 9 program studi S1 dan D3 dan 4 program studi pasca sarjana, memiliki lebih dari 200 karyawan. Mahasiswa aktif sebesar 1506 orang dengan jumlah dosen tetap dan DPK sebanyak 105 orang. Jaringan LAN terhubung ke seluruh unit-unit kerja melalui media transmisi kabel dan wireless dengan koneksi Internet. Serangan virus dan keamanan data menjadi masalah krusial dalam aktifitas berbagi file dan layanan di dalam jaringan LAN disebabkan paling banyak oleh pengguna yang tidak hati-hati dalam mengakses dan menjaga file-file terbagi. Penggunaan server hanya sebatas akses ke sistem informasi akademik secara intranet dan sebagai sebuah gateway Internet. Tidak ada penggunaan TI secara terintegrasi yang diterapkan untuk memaksimalkan interaksi dan kolaborasi pada aktifitas belajar antara mahasiswa, dosen, dan stafstaf di fakultas. FTI sebagai salah satu fakultas di Urindo mengambil inisiatif untuk dapat berkontribusi dalam cakupan yang lebih kecil sebagai pilot project dalam penerapan Google Apps for Education untuk mahasiswa, dosen, dan staf di FTI sendiri untuk menghadapi tantangan permasalahan yang ada dan mengurangi biaya TI yang memang cukup besar.
Subdomain fti.urindo.ac.id didaftarkan ke Google Apps for Education pada akhir tahun 2010. Servis-servis standar telah diaktifkan, seluruh staf dan dosen di FTI telah diberikan akun dan telah disosialisasikan pada tanggal 11 Maret 2011.

\subsection{Strategi}

FTI sedang dalam proses persiapan akreditasi dan pasca restrukturisasi organisasi internal. Keterhubungan terhadap data-data penting, dokumen-dokumen pendukung, dan koordinasi antara individu-individu di fakultas menjadi mutlak diperlukan. FTI menerapkan Google Apps for Education dengan tiga alasan utama:

a. Google mendukung secara penuh software dan hardware termutakhir dengan jaminan lisensi dan update teratur

b. Google terlihat sebagai pilihan yang kurang berisiko karena ukuran dan kelangsungan hidupnya (viability)

c. Google mendukung servis-servis yang memungkinkan metode pembelajaran online diterapkan. FTI akan menerapkan pendekatan Blended Learning yaitu kombinasi antara kuliah tatap muka atau face to face $(\mathrm{F} 2 \mathrm{~F})$ dan online learning dalam aktifitas perkuliahan. 


\section{LANDASAN TEORI}

\subsection{Cloud Computing}

Menurut Wikipedia Cloud Computing adalah komputasi, perangkat lunak, akses data, dan layanan-layanan penyimpanan yang tidak membutuhkan pengetahuan end-user dari lokasi fisik dan konfigurasi sistem untuk mengantarkan servisservis. Gambar 1 memperlihatkan diagram konseptual dari Cloud Computing, beberapa perusahaan di dalamnya merupakan penyedia layanan cloud yang terhubung satu dengan lainnya.

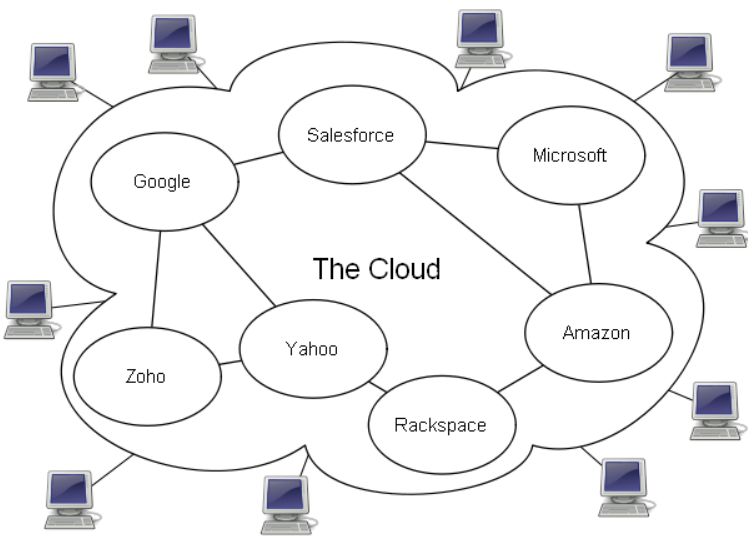

Gambar 1 Diagram Konseptual Cloud Computing

Sumber: Sam Johnston (2009)

Terdapat dua kategori cloud computing: publik atau External cloud dan pribadi (private) atau Internal cloud. Public cloud adalah sumber-sumber daya seperti penyimpanan dan aplikasi tersedia di internet oleh penyedia pihak ketiga. Servis secara khas biasanya dengan biaya murah atau dibayar berdasarkan permintaan apa yang diutilisasi.

Tabel 1 Perbandingan Platform Cloud Representatif

\begin{tabular}{|c|c|c|c|c|c|}
\hline Property & $\begin{array}{c}\text { Amazon } \\
\text { Elastic Compute } \\
\text { Cloud (EC2) }\end{array}$ & $\frac{\text { Google }}{\text { App Engine }}$ & $\frac{\text { Mikrosoft }}{\text { Live Mesh }}$ & \begin{tabular}{|c|} 
Sun \\
$\begin{array}{c}\text { Network.com } \\
\text { (Sun Grid) }\end{array}$
\end{tabular} & $\frac{\text { GRIDS Lab }}{\text { Aneka }}$ \\
\hline Focus & Infrastructure & Platform & Infrastructure & Infrastructure & \begin{tabular}{|l|} 
Software \\
Platform for \\
enterprise \\
Clouds
\end{tabular} \\
\hline Service Type & $\begin{array}{l}\text { Compute, Storage } \\
\text { (Amazon S3) }\end{array}$ & $\begin{array}{l}\text { Web } \\
\text { application }\end{array}$ & Storage & Compue & Compute \\
\hline Virtualisation & $\begin{array}{l}\text { OS Level running } \\
\text { on a Xen } \\
\text { hypervisor }\end{array}$ & $\begin{array}{l}\text { Application } \\
\text { container }\end{array}$ & OS level & \begin{tabular}{|l|} 
Job \\
management \\
sysem (Sun \\
Grid Engine) \\
\end{tabular} & $\begin{array}{l}\text { Resource } \\
\text { Manager and } \\
\text { Schedular }\end{array}$ \\
\hline $\begin{array}{l}\text { Dynamic } \\
\text { Negotiation of } \\
\text { Oos } \\
\text { Parameters } \\
\end{array}$ & None & None & None & None & \begin{tabular}{|l|} 
SLA-based \\
Resource \\
Reservation on \\
Aneka side. \\
\end{tabular} \\
\hline $\begin{array}{l}\text { User Access } \\
\text { Interface }\end{array}$ & $\begin{array}{l}\text { Amazon EC2 } \\
\text { Command-line } \\
\text { Tools }\end{array}$ & $\begin{array}{l}\text { Web-based } \\
\text { Administration } \\
\text { Console }\end{array}$ & $\begin{array}{l}\text { Web-based } \\
\text { Live Desktop } \\
\text { and any devices } \\
\text { with Live Mesh } \\
\text { installed } \\
\end{array}$ & \begin{tabular}{|l|} 
Job submission \\
scripts Sun \\
Grid Web \\
portal
\end{tabular} & $\begin{array}{l}\text { Workbench, } \\
\text { Web-based } \\
\text { portal }\end{array}$ \\
\hline Web APIs & Yes & Yes & Unknown & Yes & Yes \\
\hline $\begin{array}{l}\text { Value-added } \\
\text { Service } \\
\text { Prowiders }\end{array}$ & Yes & No & No & Yes & No \\
\hline $\begin{array}{l}\text { Programming } \\
\text { Framework }\end{array}$ & $\begin{array}{l}\text { Customizable } \\
\text { Linux-based } \\
\text { Amazon Machine } \\
\text { Image (AMI) }\end{array}$ & Python & Not applicable & $\begin{array}{l}\text { Solaris OS, } \\
\text { Java, C, C++, } \\
\text { FORTRAN }\end{array}$ & $\begin{array}{l}\text { APIs supporting } \\
\text { different } \\
\text { programming } \\
\text { models in C\# } \\
\text { and other.Net } \\
\text { supported } \\
\text { languages } \\
\end{array}$ \\
\hline
\end{tabular}

Sumber: Buyya, Yeo, dan Venugopal (2008)
Tabel 1 memperlihatkan perbandingan cloud platform. Sumber-sumber daya dialokasikan di lokasi off-site yang dikontrol oleh pihak ketiga, diakses oleh pelanggan melalui aplikasi web atau web service melalui internet. Istilah outsourcing sering digunakan untuk kategori cloud computing jenis ini. Beberapa pemain utama dari produk public cloud mencakup Amazon Elastic Compute Cloud (EC2), IBM Blue Cloud, Sun Cloud, Google App Engine, Amazon Web Services, dan Force.com.

Private cloud dimana data disimpan dan diakses oleh jumlah yang terbatas dari penggunapenggunanya di dalam pusat data perusahaan sendiri di belakang firewall. Private cloud memiliki seluruh keunggulan dari public cloud, namun di-host-kan di dalam firewall perusahaan atau departemen yang mendukungnya. Perusahaan TI masa depan di dalam private cloud dimodelkan setelah public cloud diterapkan. Salah satu fitur-fitur penting bahwa private cloud memungkinkan kedua konsumen internal dan eksternal mengakses data di dalam lingkungan lokal yang aman, hal yang membedakan private cloud dari public cloud.

\subsection{Google Apps}

Google Apps adalah sebuah servis yang menyediakan secara terpisah versi-versi yang dapat disesuaikan dari beberapa produk Google di bawah nama domain sendiri. Google Apps for Education adalah serangkaian aplikasi-aplikasi kolaborasi dan komunikasi yang dirancang untuk sekolah dan universitas.

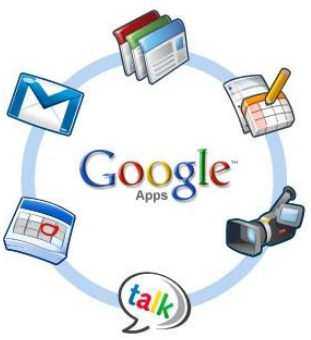

Gambar 2 Servis-servis pada Google Apps

Sumber: Google Inc.

Google Apps (lihat Gambar 2) mencakup Gmail (webmail services), Google Calendar (shared calendaring), Google Docs (berbagi dokumen, spreadsheet, presentasi secara online), Google Video (berbagi video dengan aman dan privasi terjaga), Google Sites (kreasi situs web tim dengan video, gambar-gambar, gadget, dan integrasi dokumen) termasuk juga tool-tool administratif, dukungan pelanggan, dan akses ke Application Programming Interface (API) untuk mengintegrasikan Google Apps dengan sistem TI yang ada. Dengan Google Apps Education Edition, sekolah atau universitas tidak lagi membutuhkan biaya bagi server-server dan perangkat keras, juga update dan atau lisensi perangkat lunak. Tabel 2 memperlihatkan perbandingan edisi dari Google Apps. 
Tabel 2 Perbandingan antara Google Apps Education Edition dan Premier Edition

\begin{tabular}{|l|l|l|}
\hline & $\begin{array}{l}\text { Education } \\
\text { Edition }\end{array}$ & Premier Edition \\
\hline Biaya & Gratis & $\$ 50 /$ pengguna/tahun \\
\hline Google Video & $10 \mathrm{~GB}$ & $3 \mathrm{~GB}$ \\
\hline Google Sites & $100 \mathrm{~GB}$ & $\begin{array}{l}10 \mathrm{~Gb}+500 \mathrm{Mb} \text { dari } \\
\text { pembayaran pengguna }\end{array}$ \\
\hline $\begin{array}{l}\text { Message } \\
\text { Security } \\
\text { didukung oleh } \\
\text { Postini }\end{array}$ & $\begin{array}{l}\text { Gratis untuk } \\
\text { sekolah- } \\
\text { sekolah K-12 }\end{array}$ & $\begin{array}{l}\text { Gratis untuk seluruh } \\
\text { pengguna-pengguna } \\
\text { utama }\end{array}$ \\
\hline Email Storage & $7.3 \mathrm{~GB}$ & $25 \mathrm{~GB}$ \\
\hline
\end{tabular}

Sumber: Google Inc.

\subsection{Metodologi dan Framework TEI}

Forrester Research melakukan penelitian dengan mengkonstruksikan dampak ekonomi total menggunakan Framework Total Economic Impact (TEI) bagi organisasi-organisasi yang sedang mempertimbangkan untuk migrasi ke Google Apps. Tujuan dari framework ini adalah untuk mengidentifikasi biaya, keunggulan-keunggulan, fleksibilitas, dan faktor-faktor risiko yang mempengaruhi keputusan dalam investasi.

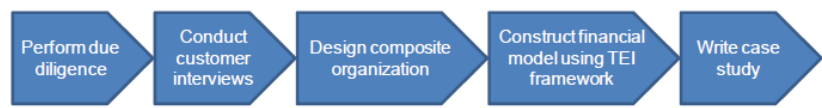

Gambar 3 Pendekatan Total Economic Impact (TEI)

Sumber: Forrester Research, Inc

Forrester melakukan pendekatan multitahap (Gambar 3) untuk mengevaluasi dampak adopsi Google Apps pada sebuah organisasi, tahap-tahap tersebut adalah:

- Melakukan wawancara kepada tim di bagian pengembangan, pemasaran, penjualan, dan penerapan produk Google kemudian analis-analis Forrester mengumpulkan data relatif ke Google Apps dan pasar bagi servis-servis kolaborasi dan pesan-pesan berbasis cloud.

- Melakukan wawancara terhadap 12 organisasi yang menggunakan Google Apps untuk memperoleh data yang terkait dengan biayabiaya, keunggulan-keunggulan, dan risiko-risiko.

- Melakukan survei kepada 600 responden TI dan end-user yang telah migrasi ke Google Apps.

- Merancang sebuah organisasi gabungan (composite) berdasarkan karakteristikkarakteristik organisasi hasil wawancara dan survei.

- Mengkonstruksikan model finansial yang merepresentasikan hasil-hasil wawancara menggunakan metodologi TEI. Model finansial dipopulasikan dengan data keunggulan dan biaya yang diperoleh dari wawancara-wawancara seperti diterapkan kepada organisasi gabungan tadi.
Forrester menggunakan empat elemen dasar TEI dalam memodelkan dampak dari Google Apps untuk mengevaluasi nilai investasi yaitu:

1. Biaya

Biaya merepresentasikan investasi yang penting untuk menangkap nilai atau keuntungankeuntungan dari proyek-proyek yang diajukan. Unit-unit TI atau bisnis bisa saja mendatangkan biaya-biaya dalam bentuk beban pekerja, subkontraktor-subkontraktor, dan bahan-bahan. Biaya-biaya menjadi pertimbangan dari seluruh investasi dan pengeluaran yang penting untuk mengantarkan nilai yang diajukan. Kategori biaya dalam TEI menangkap setiap biaya-biaya yang membengkak pada lingkungan dari biayabiaya yang terus berjalan.

2. Keuntungan-keuntungan bagi organisasi

Keuntungan merepresentasikan nilai yang diberikan kepada organisasi, unit-unit TI dan bisnis pengguna oleh produk atau proyek yang diajukan. Metodologi TEI dan hasil model finansial menempatkan bobot yang sama pada ukuran keuntungan dan ukuran biaya-biaya, memungkinkan pengujian secara penuh efek dari teknologi pada sebuah organisasi. Forrester juga membutuhkan garis yang jelas terhadap akuntabilitas yang ditetapkan antara ukuran dan penilaian keuntungan-keuntungan yang diperkirakan setelah sebuah proyek selesai.

3. Fleksibilitas

Dalam metodologi TEI keuntungan-keuntungan langsung mewakili satu bagian dari nilai investasi. Forrester percaya bahwa organisasiorganisasi seharusnya mampu mengukur nilai strategis dari sebuah investasi. Fleksibilitas mewakili nilai yang dapat dimunculkan bagi beberapa investasi tambahan di masa depan yang membangun investasi awal yang telah dibuat. Misalnya sebuah investasi di dalam perusahaan besar untuk meng-upgrade rangkaian produktivitas office yang mampu secara potensial meningkatkan efisiensi dan mengurangi biaya-biaya lisensi.

4. Risiko

Risiko mengukur estimasi ketidakpastian keuntungan dan biaya dimasukkan di dalam investasi. Ketidakpastian diukur dengan dua cara: 1) Kemungkinan bahwa estimasi-estimasi biaya dan keuntungan akan cocok dengan proyeksi awal, dan 2) Kemungkinan bahwa estimasi-estimasi akan diukur dan ditelusuri setiap waktu. TEI menerapkan sebuah fungsi densitas probabilitas yang dikenal sebagai "triangular distribution" kepada nilai-nilai yang dimasukkan. Pada kondisi minimum, tiga nilai dikalkulasi untuk memperkirakan jangkauan yang mendasar sekitar keuntungan dan biaya masing-masing. 
Metodologi TEI membantu perusahaan mendemonstrasikan, mempertanggungjawabkan, dan merealisasikan tangible value dari inisiatif TI baik bagi manajemen senior dan stakeholderstakeholder bisnis kunci yang lain.

Hasil penelitian terhadap pengguna Google Apps oleh Forrester Research menemukan bahwa organisasi-organisasi yang beragam merealisasiakan keuntungan-keuntungan tangible dalam bentuk:

\section{Keuntungan-keuntungan yang berdampak kepada $\mathrm{TI}$.}

Keuntungan-keuntungan ini meliputi penghematan biaya hasil dari perpindahan lingkungan kolaborasi dan pesan-pesan on-premise sebuah organisasi ke arsitektur berbasis cloud Google.

- Penghematan biaya mencakup penurunan pengeluaran untuk infrastruktur TI dan lisensi.

- Penghematan biaya mencakup pengurangan waktu administrator TI yang dihabiskan pada perawatan sistem, upkeep, patching, dan upgrade.

- Organisasi mencatat penghematan biaya tahunan antara $38 \%$ dan $56 \%$ dibandingkan dengan kondisi lingkungan sebelumnya.

\section{Keuntungan-keuntungan yang berdampak kepada end user.}

Bagian ini meliputi keuntungan-keuntungan end user yang spesifik sekitar migrasi dari lingkungan kolaborasi dan pesan-pesan organisasi ke Google Apps yaitu:

- Keuntungan spesifik pesan. Bagian ini mencakup penguatan produktivitas sekitar pencarian email, penyaringan spam, pengarsipan, pengorganisasian email, juga waktu respons yang diperbaiki di dalam lingkungan pesan.

- Keuntungan spesifik kolaborasi. Bagian ini mencakup efisiensi yang lebih baik dalam berbagi dan mengedit dokumen antara angggota tim, kemampuan untuk mendukung umpan balik yang lebih cepat, pertemuan virtual dan face-to-face yang lebih efisien, juga mendorong lebih sering informasi yang relevan didistribusikan ke tim.

\section{Keuntungan-keuntungan fleksibilitas.}

Bagian ini mencakup kemampuan untuk mencapai keuntungan-keuntungan sekunder dari investasi awal Google Apps.

- Kolaborasi dengan rekanan eksternal. Kemampuan untuk memperbaiki efisiensi interaksi dengan rekanan dan pemasok melalui Google Docs dan Google Sites.

- Pengaruh Pasar Google. Mengambil keuntungan dari aplikasi-aplikasi spesifik proses yang baru dari pasar Google, lwbih jauh lagi mengurangi biaya-biaya integrasi proses.

Berdasarkan temuan-temuan ini, perusahaan melihat implementasi Google Apps sebagai bagian dari strategi kolaborasi dan pesan yang mampu mengantisipasi perbaikan-perbaikan di dalam efisiensi operasional, penghematan end user dan produktivitas TI, dan keuntungan-keuntungan fleksibilitas tambahan. Penggunaan framework TEI memungkinkan banyak perusahaan menemukan potensi bagi penekanan kasus bisnis ketika membuat investasi.

\section{IMPLEMENTASI GOOGLE APPS DI PERGURUAN TINGGI}

Berikut ini beberapa studi kasus penerapan Google Apps di perguruan tinggi:

Dublin City University (DCU) berpindah ke Google Apps untuk memotong biaya TI dan memperbaiki kolaborasi. DCU adalah universitas termuda di Irlandia memiliki luas kampus 85 hektar, tiga mil ke utara terdapat sungai Liffey yang berada di kota Dublin, Irlandia. Universitas ini memiliki hampir 11.500 mahasiswa, termasuk 2.000 mahasiswa internasional dari 115 negara dengan 35.000 alumni. Selama periode waktu tertentu departemen Information Systems and Services (ISS) mengidentifikasi sejumlah isu yang mengarah kepada kondisi kritis pada sistem email yang telah ada sejak tahun 2000. Email merupakan bentuk utama komunikasi di dalam universitas, namun mahasiswa dan staf-staf akademik secara teratur menerima pesan "mailbox full" karena kapasitas maksimal 20MB per pengguna sudah tidak cukup. Sistem juga lemah kepada antarmuka web 2.0 dan tidak ada integrasi dengan sistem lain seperti kalender dan penyimpanan dokumen. Setelah melakukan penilaian terhadap sejumlah solusi email untuk sektor pendidikan, dan melalui konsultasi dan pilot project yang meliputi perwakilan staf dan mahasiswa, eksekutif universitas menetapkan implementasi Google Apps for Education pada tahun akademik 2009-2010. Makalah dipersiapkan oleh Departemen ISS dan diserahkan ke Komite Eksekutif Universitas. Setelah konsultasi dengan Google dan stakeholder-stakeholder kunci, akhirnya diputuskan untuk mengambil pendekatan "big bang" dan menerapkan migrasi bagi 45000 mahasiswa dan alumni dalam migrasi satu hari. Kapasitas penyimpanan email yang meningkat dengan Gmail telah membuat perbedaan yang nyata kepada kehidupan mahasiswa, alumni, dan departemen TI, tidak diperlukan lagi pengarsipan dan penghapusan pesan secara konstan. Selain itu mahasiswa telah menggunakan fitur-fitur Google Apps untuk 
membantu komunikasi dan kolaborasi menjadi lebih efektif.

Linköping University dikenal sebagai universitas keenam Swedia pada tahun 1975, salah satu universitas yang paling dihormati di negara tersebut. Berbeda dari organisasi akademik tradisional, Linköping dibagi ke dalam empat fakultas terpisah masing-masing memeluk budaya yang kuat pembelajaran inter-disiplinary. Pendekatan Linköping kepada kolaboratif, studi silang, dan semangat wirausaha telah mengangkatnya menjadi universitas dengan reputasi yang kuat dan pemimpin di dalam bidang pendidikan baik lokal maupun internasional.

Beberapa tahun ke depan mahasiswa di Linköping lebih banyak melaksanakan studi mereka secara online, permintaan email universitas perlu dipenuhi untuk 26.000 mahasiswa, 2.000 staf dan 300 profesor fakultas. Seluruh pengguna di Linköping telah melakukan migrasi ke Google Apps.

Sebelum implementasi ke Google Apps, pemeliharaan email menjadi salah satu pengeluaran utama bagi departemen TI di Linköping, namun saat ini universitas dapat menghemat lebih dari satu juta kronor Swedia yang dapat dialihkan untuk pelaksanaan proyek TI lain.

\section{STUDI KASUS}

Bagian ini menjelaskan tahap-tahap implementasi Google Apps for Education yang dilakukan oleh Fakultas Teknologi Informasi (FTI), Universitas Respati Indonesia. Tahap-tahap ini mengacu kepada tahapan migrasi yang disarankan oleh Google (

Gambar 4) meliputi:

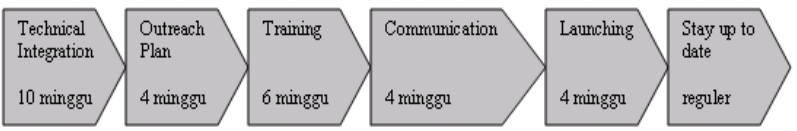

Gambar 4 Tahap-tahap deployment Google Apps

- Technical Integration

- Outreach Plan

- Training

- Communication

- Launching

- Stay up to date

Saat ini kami sedang melakukan tahap Technical Integration meliputi: Membangun rencana dan membuat tujuan, menguji produk, menguji konfigurasi pengiriman email, dan modifikasi Google Apps untuk fakultas. Kami juga sedang mempersiapkan user pilot yaitu untuk diujicobakan kepada mahasiswa, dosen, dan staf fakultas.

Kami telah menentukan alamat untuk adopsi Google Apps for Education menggunakan subdomain fti.urindo.ac.id. Seluruh servis standar telah aktif dengan pemetaan alamat (address mapping) subdomain sebagai berikut:

- Gmail: http://surat.fti.urindo.ac.id

- Google Docs : http://dokumen.fti.urindo.ac.id

- Google Sites: http://situs.fti.urindo.ac.id

- Google Calendar: http://kalender.fti.urindo.ac.id

- Google Groups: http://grup.fti.urindo.ac.id

- Startpage: http://startpage.fti.urindo.ac.id
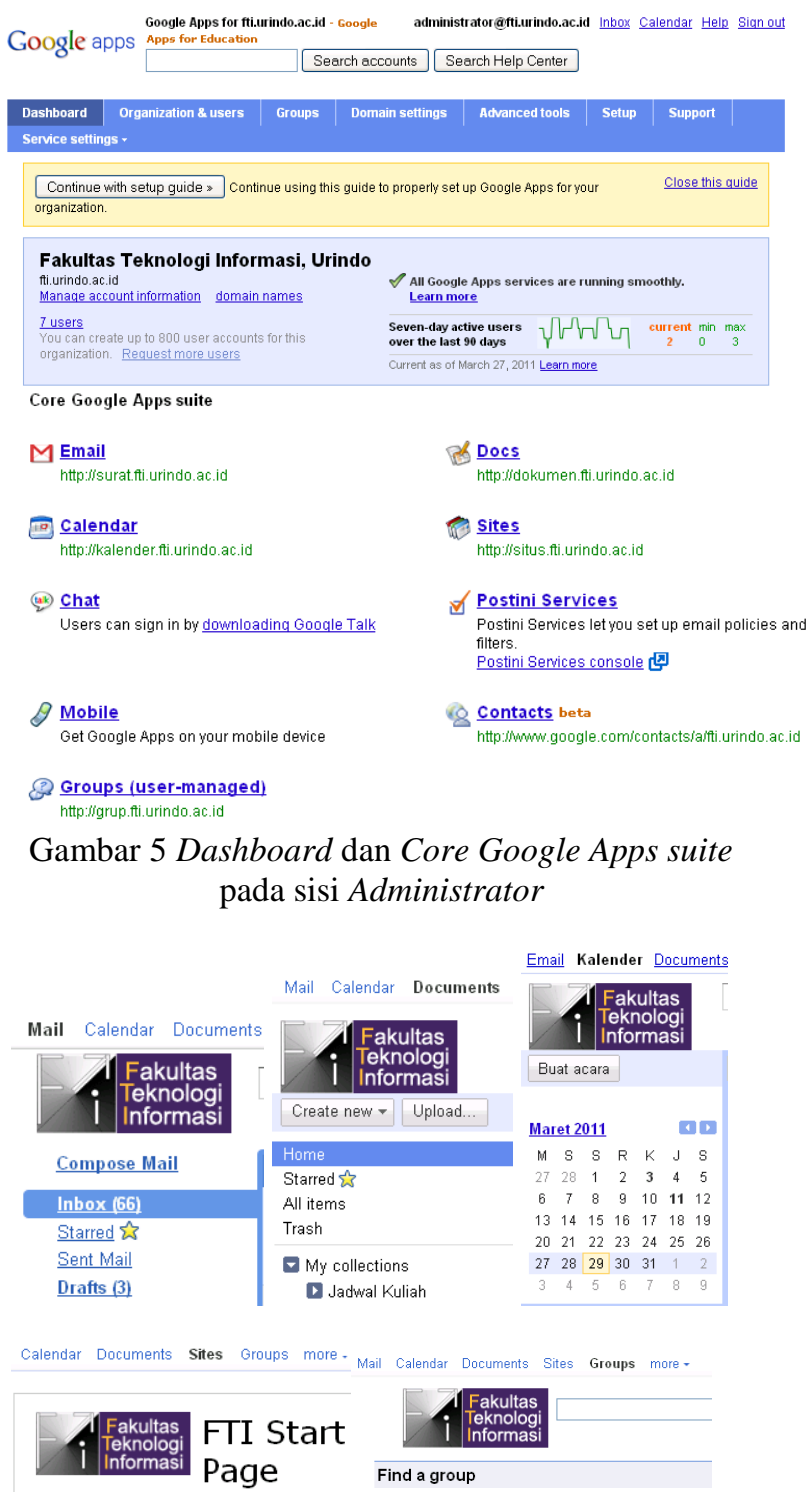

Gambar 6 Servis-servis Google Apps inti yang telah diaktifkan

Servis-servis inti yang tersedia pada Google Apps for Education di sisi administrator seperti terlihat pada Gambar 5. Google Sites, Google Docs, Gmail, Google Contacts, dan Google Calendar yang digunakan untuk kolaborasi dan kuliah online dapat dilihat pada Gambar 6 .

Kami sedang melakukan ujicoba kepada kinerja email dan juga mengkondisikan servis-servis lain untuk memaksimalkan kolaborasi, dan proses pembelajaran dan pengajaran. Saat ini proses deployment masih sedang berlangsung. 


\section{KESIMPULAN}

Implementasi Google Apps for Education memberikan solusi yang logis bagi fakultas, mahasiswa, dosen, dan unit bisnis lainnya di institusi kami di atas kondisi infrastruktur TI yang belum mapan dan terencana. Pengalaman implementasi Google Apps edisi standar sejak tahun 2008 terhadap proses pembelajaran menerapkan metode Blended Learning dengan membuat situs web kuliah dalam hitungan menit, dokumentasi materi-materi kuliah dalam bentuk elektronik, manajemen waktu dengan kalender, dan kolaborasi dalam pembuatan tugas oleh mahasiswa memberikan fleksibilitas dan kenyamanan bagi kami, personalisasi dapat diatur antar user dengan mudah. Keuntungan yang signifikan adalah bahwa investasi TI kecil atau hampir nol namun berdampak besar terhadap penghematan biaya lisensi, upgrade, dan pemeliharaan perangkat keras dan perangkat lunak.

\section{PUSTAKA}

Nucleus Research (2009). ROI Case Study Google Apps TVR Communications. Diakses pada 28 Januari 2011 dari http://reseller.googleapps.com

TechRepublik, ZDNet, dan BNET (2009). Cloud Computing-What is its Potential Value for Your Company?. CBS Interactive Inc. Diakses pada 12 Desember 2010 dari http://www.bitpipe.com.

Baca, S. (2010). Expert References Series of White Papers: Cloud Computing: What It Is and What It Can Do for You. Global Knowledge. Diakses pada 12 Desember 2010 dari http://www.globalknowledge.com.

Buyya, Yeo, Venugopal (2008). Market-Oriented Cloud Computing: Vision, Hype, and Reality for Delivering IT Services as Computing Utilities. Diakses pada 12 November 2010 dari http://arxiv.org/ftp/arxiv/papers/0808/0808.3558. pdf

Erickson J. dan van Metre E. (2010). Measuring The Total Economic Impact of Google Apps. A Cross-Industry Survey And Analysis, Forrester Consulting. Diakses pada 12 Desember 2010 dari http://www.bitpipe.com.

Schadler, T (2009). Should your Email Live in The Cloud? A Comparative Cost Analysis. Forrester Consulting. Diakses pada 11 Desember 2010 dari http://www.bitpipe.com.

Nejdeby, J (2010) Linkoping University Case Study. Google Inc. Diakses pada 11 Desember 2010 dari http://googleapps.com.

McConalogue, B (2010). Dublin City University moves to Google Apps to Cut Costs and Improve Collaboration. Google Inc. Diakses pada 11 Desember 2010 dari http://googleapps.com. 